\title{
Философия свободы в романе Дениса Соболева Иерусалим: на пути от отказа к возможному
}

\author{
ROMAN KATSMAN \\ Bar-Ilan University, Department of Literature of the Jewish People, IL-5290002 Ramat-Gan \\ E-mail: roman.katsman@biu.ac.il
}

(Received: 16 September 2017; accepted: 27 November 2017)

\begin{abstract}
The present paper dwells upon the subject and the conception of freedom in the novel Jerusalem (2005) written by the Russian-Israeli writer, poet and scholar Dennis Sobolev. According to this conception, the fragmentariness of the being serves as the foundation for the search for freedom. This search consists of renunciation of the world of absolute power. The renunciation enables apprehension of freedom as a possibility in the splits between the fragments of the being. In the novel, this search for the real order of freedom beyond the imagined chaos of history unfolds within the symbolic order of Jerusalem - the earthly, political, and mystical city, which is presented through the eyes of seven narrators in seven separate and united stories. Dennis Sobolev's work thus reveals as a dissipative novel-myth about the disparate attempts to constitute the realistic and skeptical, and at the same time spiritual and playful, ontology.
\end{abstract}

Keywords: D. Sobolev, Russophone literature, Israel, philosophy of freedom, Jerusalem

\section{Введение}

Одно из основных интеллектуальных усилий литературы направлено на воображение свободы - будь то свобода от путаницы идеологий или свобода создания этих идеологий, свобода выбора или свобода уклонения от выбора. Литературное воображение свободы (и несвободы), как известно, неоднократно становилось предметом изучения философов и антропологов, будь то в качестве материала или в качестве иллюстрации. Достаточно упомянуть интерес Рудольфа Штейнера к Гёте, Вячеслава Иванова - к Достоевскому, Исайи Берлина - к Тургеневу и Толстому, Жиля Делёза - к Кафке, Мераба Мамардашвили - к Прусту, Владимира Кантора к Шекспиру. ${ }^{1}$

В число писателей, поглощенных размышлениями о свободе, входит и Денис Соболев - урожденный петербуржец, а ныне - израильский ученый, писатель, поэт, о котором пойдет речь в этой статье. Его дискурс свободы наполнен одновременно ужасом и бесстрашием: ужасом перед лицом существования и бесстрашием отказа - как от страха существования, так и от самого существования. Как будет показано ниже на примере романа Иерусалим (2005), этот дискурс складывается из следующих основных тем или идеологем: фрагментарность бытия, кровавый хаос истории является основой

${ }^{1}$ См. также специальные исследования и рецензии, как например ГуляЕВ 2015, АТОЕВ 2015, ОРОБий 2014. 
поиска свободы (и, возможно, истины); суть этого поиска - в отказе от мира всевластия; отказ приводит к схватыванию свободы как возможности, в промежутках между фрагментами хаоса бытия.

В результате, свобода мыслится в романном дискурсе Соболева как своего рода диссипативная структура, в терминах теории хаоса (см. НиколисПригожин 2003), имеющая вид такого конечного, интеллигибельного живого лика, который непредсказуемо и кратковременно проступает на поверхности мирового хаоса, но при этом изменяет картину мира необратимо. Вырастающее из раздробленности существования и отказа от любой властной связности мышление возможного переводит восприятие из порядка воображаемого в порядок реального, при посредстве символического порядка Иерусалима. Таким образом, роман-миф раскрывается как своего рода диссипативный Bildungsroman о духовном и интеллектуальном становлении личности, погруженной в пары иерусалимского синдрома. ${ }^{2}$

Иерусалим может быть поставлен в один ряд с другими русско-израильскими иерусалимскими, магическими или нет, романами последних двух десятилетий, имеющими сходную поэтическую и идейную, если не сюжетную, структуру. Это, прежде всего, роман-сеть И/е рус.олим Елизаветы Михайличенко и Юрия Несиса (МихАЙличенко-НЕсис 2004) и роман-апокриф Черновики Иерусалима Некода Зингера (Зингер 2013) (последний тем более близок к роману Соболева, что он состоит из цикла рассказов, сюжетно не связанных ничем, кроме места действия - Иерусалима). «Сказка» Михаила Юдсона Лестница на шкаф (Юдсон 2013) также представляет собой многосоставную конструкцию с многоликим героем, но, в то же время, она является антиподом романов Соболева и Зингера, ибо в ней судьба одного героя последовательно и вполне в духе фольклорного путешествия соединяет три локуса: Россию, Германию и Израиль.

Цикл рассказов Леонида Левинзона «Гражданин Иерусалима» (ЛЕвинзон $2013)$ структурно подобен роману Соболева и тем более близок к нему, что символически объединяет Иерусалим с Петербургом. Можно упомянуть также книгу писателя другого поколения, ныне проживающего в России, Михаила Федотова Иерусалимские хроники (ФЕдотов 1989), которая состоит из многочисленных фрагментов, очерков, зарисовок и жанровых сцен. И, наконец, в этот ряд следует поставить также иерусалимские или «пара-иерусалимские» романы Дины Рубиной: Bom идет Мессия! (Рубина 1996), романкомикс Синдикат (РуБинА 2004) и «испанская сюита» Последний кабан из лесов Понтеведра (РуБинА 1998). Для всех этих писателей Иерусалим служит символической ареной проблематизации исторических и личностных нарративов, поисков свободы среди фрагментов, игр, фантазий, безумий и снов существования.

${ }^{2} \mathrm{C}$ этим сходен также новый фрагментарный, диссипативный «роман места» Соболева сказки, связанные с другим израильским городом, Хайфой, которые публиковались в периодике с 2009 года и были изданы как роман Легенды горы Кармель в 2016 году. Хайфские сказки требуют отдельного исследования, поэтому здесь они рассмотрены не будут. 
Романы Соболева, Михайличенко и Несиса, Зингера, Юдсона возникли как ответ на вызов постистории. Каждый по-своему, они восстанавливают причастность актуального к исторической памяти и к историческому знанию: Черновики Иерусалима - через изобретение новых исторических сюжетов, И/е рус.олим - через проживание старых, Лестница на шкаф - через прошивание текстов и пространств новым, небывалым языком, прорастающим сквозь все существующие и уже не справляющиеся с древней задачей воссоздания истории такой, какой она могла бы или должна была бы быть. Однако даже если история - это, как в упомянутых романах, зачеркнутый текст, сеть, нечленораздельное бормотание или все это вместе взятое, она все же существует и она жива, одновременно любима и ненавидима, высмеиваема и оплакиваема. Именно векторами направленных на нее страстей, истерических и риторических жестов присвоения и отчуждения, она и ограничивается, превращаясь в остров или, точнее, в сеть островов, в архипелаг. Роман Соболева, как и его культурологический opus magnum Eвреи и Европа, а также хайфские сказки - это ответ писателя постисторическому нигилизму и релятивизму. Используя образы Соляриса Станислава Лема, можно сказать, что произведения Соболева моделируют историю как архипелаг островов личностного сознания в океане воспоминаний, желаний, страхов, надежд, любвей и вин. По словам Матвея Кагана, роман как жанр как раз и служит средством индивидуации и персонализации общественного исторического сознания, своего рода индивидуальным ликом, которым одно сообщество обращается к другому (КАГАн 2004: 579). В этом смысле, роман Соболева вполне показателен как выражение островного, фрагментарного, разорванного, сказочно-бредового, но, в то же время, предельно неповторимого и наполненного жизнью актуально-исторического существования Иерусалима, Израиля, еврейского народа.

Иерусалим состоит из семи глав, семи не связанных друг с другом историй, рассказанных семью ненадежными повествователями. Их объединяет только сходство с автором: они эмигранты из России, живущие в Иерусалиме и пытающиеся хоть как-то осознать не поддающуюся пониманию действительность, в которой война и террор соседствуют с духами, вампирами, ангелами и мифическими персонажами. В первой главе «Лакедем» рассказчик, филолог, рассказывает о своем знакомстве с Вечным жидом и о поисках неизвестного рассказа Ишервуда. Во второй главе «Самбатион» рассказчик встречается с женщиной-демоном Лилит и другими мифическими существами, читает древние рукописи о потерянных коленах Народа Израиля и ведет философские беседы с друзьями. Третья глава «Двина» рассказывает историю о женщине, похоронившей семерых мужей, и о демоне Ашмодее, а сам рассказчик, математик-докторант, страдает от несчастной любви и едва не кончает жизнь самоубийством. В главе «Орвиетта» повествователь пишет роман о талмудическом мудреце Элише бен Абуйе, а также знакомится с женщиной-вампиром. Рассказчик в главе «Азаэль» едва не теряет рассудок, бродя по таинственным иерусалимским улицам и воображая себя ангелом из 
еврейских мифов. В «Квесте номер 6» накладываются друг на друга компьютерная игра, ролевая игра по мотивам романа-фэнтези и конспиративная теория об убийстве Ицхака Рабина. В последней главе «Дерево и Палестина» рассказчик занимается историей хазар. Все повествователи встречаются на резервистских сборах, с тем чтобы автор смог подвести не подытоживающий итог их мучительных и порывистых исканий.

\section{Фрагментарность как пространство свободы и безумия}

Поиск свободы начинается с феноменологии фрагментарности, с осмысления языка, на котором ведется разговор о хаосе существования. Принцип фрагментарности, столь распространенный в современной русской литературе, находит в романе Соболева философское обоснование: «Фрагментарность исчезает только в царстве воображаемого. И именно поэтому пишущий... вынужден выбирать между истиной и последовательностью. Я не хотел выбирать иллюзорную цельность, легкую убедительность несуществующего, но уже не мог выбрать истину» (СоБолев 2005: 225). ${ }^{3}$ Фрагментарность есть сама истина и, в своей трудной убедительности, сама реальность. В другом месте рассказчик по-платоновски уподобляет обретение истины возвращению на родину, вспоминанию себя, своего дома - «анамнезису» (121). В главе «Дерево и Палестина» героиня говорит рассказчику, который пишет книгу о хазарах: «Наша жизнь фрагментарна, разнородна и непоследовательна. [...] А в книге у тебя будет вполне видимая цельность: цельный сюжет, цельный стиль, цельный характер. [...] А судить такую книгу будут, исходя не из истины, а из законов жанра, потому что мы смотрим на мир сквозь эти законы, а не наоборот» (418-420). И далее она формулирует то, что можно назвать философским манифестом непрозрачности: «распад иллюзий, непрозрачность бытия, неоднородность, непоследовательность, фрагментарность, случайность, излишность, отказ от сюжета и единого стиля» (421). Рассказчик соглашается с ней, особенно в том, что касается противостояния идее прозрачности «Я», перекликающейся с принципом прозрачности, визуальности в современной и постсовременной культуре. Но, в то же время, он отказывается видеть в составляющих этого манифеста причину для отказа от поиска истины за пределом витгенштейновских «словесных игр», потому что такой отказ означал бы забвение, молчание и покой (423).

Признавая трансцендентный характер истины, сомневаясь в ее существовании, он, тем не менее, не готов отказаться от того, что Поль Рикёр назвал усилием вспоминания (RICOEUR 2004: 28-42), хотя рассказчик и не отождествляет его с конфигурацией нарратива и сюжета (РикёР 1998: 65-106), а скорее, противопоставляет их. Его систематический скептицизм состоит в том, что такой вспоминающий «будет часто спрашивать себя, помнит ли он

${ }^{3}$ Дальнейшие ссылки на роман Д. Соболева Иерусалим будут даваться в статье с указанием цитируемых страниц в скобках. 
истинное, или вымышленное, или ни то, ни другое; не бродит ли он кругами среди бесчисленных отражений собственной меланхолии, и еще: не лучше ли забыть о том, чего нет. Правда ли то, что он помнит, что он думает, что помнит» (423). В этом воображаемом споре Рикёра с Витгенштейном побеждает Платон, а точнее Сократ, чей метафизический голос систематически деконструируется, фрагментируется, прерывается вопрошанием о воспоминании, вопрошанием, которое и есть само воспоминание. Другими словами, в неокантианских терминах Германа Когена, мысль есть мысль об источнике мысли, челночные колебательные движения от мыслящего к мыслимому, самим этим колебанием ставящие и то, и другое под сомнение, однако абсолютно неизбежные (COHEN 2005: 36). В каждом таком движении туда и обратно рождается один фрагмент, одинокий остров в океане забвения и незнания, а множество островов составляют вечно меняющийся архипелаг, который не имеет заранее заданной формы, а является, в терминах того же Когена, повторенных позднее Бахтиным, заданием (БАхтин 1986: 111). Фрагментарность есть форма мышления, и направлено оно здесь, вполне не постмодернистски, онтологически, на поиск истины и свободы и взаимоотношения между ними. ${ }^{4}$

Методом поиска свободы для семи повествователей в семи главах романа служит отождествление с историческими или мистическими личностями, либо с целыми эпохами, и главным инструментом в этом методе оказывается временной и личностный разлом, выход из под власти самотождественности. В главе «Дерево и Палестина» рассказчик размышляет о «пространствах свободы» (391) - понятие, восходящее к концепциям Теодора Адорно (см. Адорно 2000: 37). ${ }^{5}$ В его сознании происходит временной скачок (392) - и он обнаруживает себя в одном из таких пространств, а именно в столице Хазарского каганата Итиле. В этом, по его словам, «городе свободы» (393), он встречается с хранителем библиотеки кагана, а потом отправляется на поиски некоей тропы, начинающейся у раздвоенного белого столпа у слияния черных рек (395). Вычерченную на карте кагана тропу найти, вероятно, невозможно, но карта хранит «потаенную и недостижимую истину» (396). Герой, вопреки предостережениям хранителя библиотеки, отправляется на охоту за ней, на поиски точки «слияния черных рек», следуя, как он говорит, «обманчивым и правдивым знакам темноты» (397).

Метод историко-мистического отождествления имеет и свою мрачную сторону. Герои Соболева, как и герои многих других иерусалимских романов, страдают от иерусалимского синдрома. Иерусалим до такой степени насыщен мифами, что иногда люди, особенно попадающие в него впервые, начинают чувствовать себя их героями или свидетелями. В главе «Азаэль» появляется рассказчик, который заканчивает свой путь в сумасшедшем доме

\footnotetext{
${ }^{4}$ Историю и систематическое рассмотрение этого вопроса см. Никитин 2002, СтЕКловА 2015.

${ }^{5}$ См. также обсуждение философии Адорно (СоБолЕв 2008: 312). Кроме того, в одной из хайфских сказок Соболева, Поезд Хайфа-Дамаск, фамилия главного героя совпадает с фамилией Адорно по отцу - Визенгрунд (СоБолЕв 2011).
} 
после снов об ангелах и фантазиях о том, не является ли он ангелом Азаэлем, безрезультатных попыток излечиться от галлюцинаций и приступов тоски, а также унижений со стороны жены. Однако это безумие связано с иерусалимским синдромом лишь отчасти. Он видит сон о спуске ангелов с небес, который напоминает, конечно, о сне Иакова (другой сон Иакова, тот, в котором тот становится Израилем, упоминается в главе «Двина»-162). Но впервые именование «Азаэль» по отношению к рассказчику (или его другу) прозвучало еще в питерской квартире, задолго до репатриации в Израиль, из уст одного странного еврея, нищего гостя-бродяги, впоследствии встречающегося герою в Израиле, вполне фольклорного персонажа - то ли скрытого воплощения вездесущего пророка Илии, то ли тайного мистика. Развертывание магического имени, мифа, в терминах Лосева, связывает разнородные моменты пространства-времени в единую личностную историю, чудесным образом реализующую некую трансцендентальную цель. Именно поэтому его «безумие» видится рассказчику как обретение свободы и возвращение (305) понятие, имеющее в романе платоновский смысл вспоминания, узнавания истины, а также преодоления боли утраты. В терминах упомянутого в главе «Самбатион» Фомы Аквинского (86), это означает обретение веры, освобождение от ада отчуждения. В этом смысле, безумие Азаэля раскрывается как священное безумие, обретение бога в душе и сноподобная борьба с ним, превращающая Иакова в Израиля. Душевная болезнь и затворничество в духе булгаковского Мастера представляют современное состояние конфликта человека и общества в его наиболее острой форме, а именно как «бегство от свободы» (ФРОмм 2011).

\section{Всевластие, отказ и свобода}

В книге Соболева Евреи и Европа осознание свободы представлено как важнейшая особенность европейской и еврейско-европейской литературы, что позволяет автору сопоставить, например, Авраама ибн-Эзру и Иосифа Бродского (СоБолев 2008: 97). Голос Соболева созвучен как с русской классикой, так и с Франкфуртской школой и французской философской антропологией и культурологией ХХ в. Исходя из иных культурных и идейных предпосылок, автор сближается с такими религиозно мыслящими философами свободы, как Сергей Левицкий, и видит свободу как абсолютно необходимое условие дискурса как акта выбора, существования и познания (см. ЛЕвицкий 1995). Впрочем, Соболев идет еще дальше, доводя это обусловливание, как будет показано ниже, до акта отказа, так что, если перефразировать известные слова Достоевского, то он мог бы сказать: если б кто доказал, что свобода вне бытия, то лучше бы оставаться со свободой, нежели с бытием. Соболев не отождествляет свободу и существование или свободу и внутренний долг, как Карл Ясперс (см. ЯспЕРС 1991), но проблематизирует это тождество через разнообразный опыт своего многоликого героя. 
Роман стоит в стороне как от социал-демократической или марксистской проблематики взаимоотношений маленького человека с властью и идеологией, так и от романтической или авангардистской проблематики поэта и власти. Во многом отталкиваясь от воззрений Адорно, в частности его лекций Проблемы философии морали, Соболев выстраивает контекст, в котором сталкиваются, теснятся и спорят многочисленные философские голоса и который можно назвать «мысль и бытие» или «истина и речь», а также «справедливость и закон» или «свобода и долг». Именно поэтому его главным борцом за свободу или против власти становится талмудический мудрец, законоучитель и теолог рабби Элиша бен Абуйа, герой и двойник рассказчика в главе «Орвиетта». В отношении него сформулирована главная мысль, проясняющая особенности интерпретации Соболевым темы свободы и власти.

Об Элише, прозванном в Талмуде «другим» (часто используемая формула, замещающая его имя при представлении мнений различных мудрецов по тем или иным вопросам), у Соболева сказано: «Так он стал Отказавшимся, стал Другим» (218). Если контекст великого Отказа перед лицом власти вполне очевиден, соотносясь как с антибуржуазными идеями Франкфуртской школы, которым Соболев уделяет немало внимания в книге Евреи и Европа (СоболЕв 2008: 290), так и с советским понятием отказничества и с израильским понятием пацифистского серув'а (отказ, на иврите), то интерпретация понятия «другого» требует пояснения. В социологическом неомарксистском дискурсе «другой» - это тот, кому отказано (меньшинство, угнетенный, бесправный), а не тот, кто отказался сам. Исключение составляют только крайний индивидуализм и анархизм (одинаково чуждые Соболеву и его герою), так как они не уточняют и не решают, а снимают проблему другого. С другой стороны, в философии, например, Эммануэля Левинаса, «Другой» - это Бог, Лик, тайна или смерть, будущее, источник существования субъекта да и самого мироздания (ЛЕвинАс 1998: 77-89), а отнюдь не тот, кто, как Элиша, отказывается это мироздание принимать и признавать за ним право на творение. Пожалуй, он мог бы сказать, вслед за Иваном Карамазовым: «В окончательном результате я мира этого божьего - не принимаю, и хоть и знаю, что он существует, да не допускаю его вовсе. Я не бога не принимаю, пойми ты это, я мира, им созданного, мира-то божьего не принимаю и не могу согласиться принять» (Достоввский 1982: 277). Другой рассказчик даже обращает к Богу прочувствованный монолог и говорит, что этот мир не для него (162). В произведении Евреи и Европа Соболев упоминает также концепцию Адорно об искусстве как отказе: «Отвечая гримасой на гримасу мира, модернизм отказывается от компромисса, от соглашения с миром, от утешения и утешенности. Модернизм - это цветаевский отказ, обращенный к миру; его логическое завершение в книгах Беккета. Согласно Адорно, модернизм и искусство вообще - это отказ» (Соболев 2008: 313-314).

Дальнейшее развитие этой мысли у Соболева движется в русле пламенной речи Ивана, а также отвечает Ницше на его попытки заглянуть в бездну и оказаться по ту сторону добра и зла: «Именно тогда он (Элиша) и заглянул 
в бездну истории медленно и осторожно, как свешиваются со скалы в пропасть, проверив камни на самом краю, увидел ее всевластие и ее ужас. [...] Он увидел всевластие зла» (218). Итак, не только и не столько власть является причиной и предметом отказа, сколько ее тотальность: всевластие истории и зла, а также всевластие как таковое. Если в самом зле еще можно найти, как это делает Ханна Арендт, основание для его банализации и сведения к подчинению закону (АРЕндт 2008), то всевластие зла полностью исключает такую возможность, и отказ Элиши - это также и отказ миру в его оправдании, но не Богу. Не сами языки власти, но их «всесильность» отвращает Элишу от мира и мешает встретиться взглядом с Богом (169). «Всевластие зла» противоречит чувству справедливости, но не вере (170). Элиша страдал от «всевластия несправедливости и лицемерия», но освобождения искал не в одиночестве и отчуждении, а в «способности противостоять бытию, чистого и бескорыстного разрушения, безжалостности, светящихся глаз, силы, мести и преодоления» (171). И, чтобы эта революционность не показалась частичной или не достаточно радикальной, рассказчик, придумавший этот образ Элиши, приписывает ему «молчаливый бунт против всевластия мироздания» (185). Он и сам пытается пробить «брешь в стене всесильности власти и неизбежности» (208) и, как и другие рассказчики в романе, приходит к идее абсолютного прощания (185). Только оно и есть подлинное освобождение, только оно и может противостоять «властвованию как идее и как форме бытия» (219), поскольку любая другая форма противостояния мирозданию или слияния с ним есть лишь еще один из языков власти.

Тотальность отказа, прощания, утраты противостоит тотальному всему и освобождает от него, конституирует такого «другого», который только и может быть подлинным «я». Ни Фуко с его «бесстрашной речью», ни Барт с его «нулевой степенью письма», ни Деррида с его деконструкцией и обрезанием не в силах противостоять всесильности всего, поскольку не готовы отказаться от всего. Но все же этого крайнего негативизма не достаточно, чтобы обрести свободу. Парадоксально это или нет, но именно рассказчик главы «Орвиетта» менее всего озабочен ее позитивным представлением. Мы обнаруживаем ее следы в других главах.

Здесь, как и в истории об Элише, ключом к пониманию власти является ее тотальный характер: всевластие денег (59), всевластие закона (65), всевластные идеологии (432), а в книге Евреи и Европа, говоря о Вальтере Беньямине, Соболев упоминает и «всевластие языка» (см. Соболев 2008: 230). В последней главе, в которой все семь рассказчиков встречаются на военных сборах, подводится неутешительный итог их поисков и борьбы: «Следование долгу и было тем последним, что нам оставалось» (432). Но, в то же время, утверждается, что они «толкаемы к свободе самой сущностью своего бытия, глубинной и непреодолимой непринадлежностью» (432). Увы, и это утверждение, следующее в русле философии Ясперса, не может быть ничем иным, кроме как еще одним, не вполне адекватным и вполне спорным суждением последнего, но отнюдь не самого авторитетного из рассказчиков. И Кант, 
с его понятием долга, и критика этого понятия Адорно (ср. Адорно 2000, лекции 12-14), включаются в дискурс Соболева как неуверенные и противоречивые голоса. На деле, каждый из шести других рассказчиков указывает на свой путь к свободе. В главе «Самбатион» свободна только женщина-демон Лилит, хотя и не счастлива, «исключенная, если не из всеобщего закона страданий, то, по крайней мере, из бесконечного круговорота рождений, надежд, лжи, страхов, смертей» (50). Это - свобода от грусти, Евиного проклятия. Здесь же герой провозглашает свою свободу от долга: «Я никому ничего не должен, - продолжал я, - ни стране, ни Богу, ни вере, ни искусству, ни даже свободе; никто из них не существует для меня; я должен только самому себе» (61). В главе «Двина» существует даже «бесконечное пространство свободы» (162), лишь едва прерываемое «дальними, иллюзорными огнями, искрами самообмана и рабства». В главе «Орвиетта» картина осложняется образом Элиши, но, похоже, что для самого рассказчика свобода - это синоним счастья, полноты жизни (207-208), в противоположность «свободе в пустоте» рабби Элиши (226). В главе «Азаэль» свобода обретается не где-нибудь, а в сумасшедшем доме, вполне в духе Macmepa и Mapгapumbl - одного из главных романов о власти и свободе в XX веке (намек на роман Булгакова можно увидеть и в полете всадников во сне рассказчика). И наконец, в главе «Квест номер 6» создается пространство свободы как пространство игры, будь то компьютерная военно-стратегическая игра или ролевая игра в лесу по не существующему фантазийному роману не существующего писателя, или игра в теорию заговора об убийстве Ицхака Рабина.

\section{Свобода и философия возможного}

И все же что-то объединяет все эти пути свободы, и в чем-то последний рассказчик оказывается прав: не зря же именно он командует отделением рассказчиков-резервистов, охраняющих поселение. Все пути к свободе - это пути долга, но не совсем в том смысле, который имеет в виду рассказчик в главе «Дерево и Палестина». Это, скорее, долг преодоления боли утраты, poena damni Фомы Аквинского (86), при абсолютной невозможности преодолеть саму утрату. Странным образом, речь об этом долге ведется не в модальности долженствования, ибо оно есть язык власти, и не в модальности существования, ибо оно есть всевластное всё, а в модальности чистой нереализованной возможности, так как она описана, например, в Философии возможного Михаила Эпштейна (см. Эпштейн 2001), и намек на которую содержится уже в одном из эпиграфов к роману - в цитате из слов обезумевшей Офелии: «Господи, мы знаем, что мы есть, но мы не знаем, чем мы могли бы быть» (7). Первые две скомпрометировали себя своей связностью, нарративностью, иллюзорной цельностью, то есть тотальной всесильностью, в то время, как последняя делает возможным такое пространство, такую речь, в которой все голоса, все рассказчики и истории существуют не иначе, как в виде города-архипелага, диссипативной структуры. 
Так темы власти и свободы перекликаются с композиционной семиглавой формой романа, в которой иерусалимское пространство храмового семисвечника сливается с эллинским пространством Семивратных Фив, основанных Кадмом, возможно, еще одним двойником Лакедема, ведь оба имени образованы от одного семитского корня К.Д.М., что означает одновременно «древность» и «восток». Сама эта форма романа представляет собой, выражаясь в терминах Лотмана, взрыв возможностей (ЛотмАн 2000: 101-116), сингулярность, единственную точку, в которой все возможно и ничего нет, и где поэтому не властна никакая власть и торжествует свобода. Рассказчик в главе «Двина» преодолевает боль и утрату, соскальзывая «в счастливое сумеречное пространство между реальностью и воображением, где память, качаясь на пороге, превращалась в силуэт возможного и уже переставала жечь рваную кожу души» (138), где он слышит «голос, исходящий из небытия, из чистой возможности, из иного» (139). Роман, таким образом, воплощает то, что в произведении Евреи и Европа Соболев называет «поэзией существования», «обнажением подлинности существования, хотя бы и во всей его неуниверсальности и историчности, [которое,] хотя и неотделимо от истории, уже не является исполнением воли власти» (СоБолЕв 2008: 391). ${ }^{6}$

Тема свободы и противостояния всевластию укореняется в философии возможного, а также в поэтике и философии фрагмента, острова, архипелага. Причем это укоренение или вживление происходит отнюдь не в русле постструктуралистских концепций, таких, например, как ризома Делёза и Гваттари (Делёз-ГвАттАРи 2010, глава 1). Скорее, наоборот: если у французских мыслителей любой нарратив распадается и оказывается случайным набором означающих, различений и откладываний, любое из которых может быть соединено с любым другим, то у Соболева любая случайная точка континуума, любой знак может оказаться структуро-порождающим источником, вероятностной, поссибилистской составляющей некоего появляющегося и исчезающего, то есть диссипативного нарратива. Как говорит рассказчик в главе «Лакедем», литературовед, занятый поиском неизвестного рассказа Кристофера Ишервуда, «любой отрывок, чье происхождение было не выяснено, мог оказаться частью той же повести» (21).

Определяющей здесь является модальность возможного. Следует отметить, что она отличается также от хорошо известной в современной литературе неопределенности видимого и реального, идущей от барокко и романтизма к Гоголю и Кафке, и далее к Кальвино и Пелевину. Мысль и дискурс Соболева движутся не в плоскости упомянутой дихотомии, снимающей возможность (и необходимость) любой эпистемологии, а в русле того, что в еврейской традиционной экзегетике называется драш: такая интерпретация отдельного фрагмента, которая позволяет включить его в потенциально неограниченное множество возможных нарративов, при том что сам нарратив видится не как заранее установленная закрытая длительность, но как постоянно

${ }^{6}$ Соболев также добавляет: «поэтическая речь в том ее понимании, о котором шла речь выше, возможна не только в поэзии, но и в прозе» (СоБолЕв 2008: 393). 
меняющаяся самопорождающая динамическая система. Как говорит один из героев романа, в этом мире все связано со всем или подобную связь всегда можно изобрести (150). В этом случае, неопределенность типа «может быть, а может и не быть» является не обманом восприятия или ошибкой мышления, не недостатком знания или понимания, а фундаментальным законом смыслообразования и, вообще, как учит теория хаоса, законом мироздания.

Единство субъекта, сохраняющееся, несмотря на все судороги и надломы диссипативности и фрагментарности, называется в романе Домом - тем, что, по словам Джона Раскина, не нужно заслужить (32), то есть отыскать среди расходящихся тропинок, получить как приз в игре; тем, чего не может не быть даже у Вечного жида Лакедема, героя одноименной главы (34). Чем, в таком случае, может быть грусть Лакедема «как будто у него нет дома» (34)? Грусть - это печать проклятия, изгнания, отлучения или, говоря языком романа, свойственным отчасти и хайфским сказкам, непринадлежности (47). Она же - признак бунта против всевластия всего, признак великого отказа, которым отмечены рассказчики и некоторые герои романа (224). Грустью во взгляде последнего рассказчика на землю, подводящего итог «отказу», и завершается роман (432-434). Но, в то же время, этот отказ или утрата являются источником той «щедрости», к которой «рай непричастен» (47), которая делает возможным сам рассказ, саму историю, как в Библии она делает возможным деторождение. Кроме того, благодаря непринадлежности, «душа неожиданно получала краткую возможность заглянуть за край существования в бесконечное пространство истины» (121).

Грусть препятствует непрерывному переживанию «дома», т. е. истины как возвращения и принадлежности. Именно она создает фрагментарность речи и нарратива, а не интеллектуальная игра, идеологическая убежденность или эстетическое экспериментаторство. Обнаруживающийся таким образом эмоциональный или, точнее, феноменологический характер фрагментарности согласуется с концепцией культуры как диссипативной системы. «Дом» всегда существует, но переживать его можно только отдельными частями, феноменами - как Лакедем, так, как будто его нет.

Эту же концепцию - «как будто» - мы встречаем в словах одного из героев главы «Самбатион» Джованни, обращенных к другому персонажу, Андрею: «Когда мир перестает прятать свое лицо, становится ясно, что это огромная мозаика, но совершенно бессмысленная. Нелепая, пустая, уродливая; и первое, самое естественное чувство - это желание встать в стороне, посмотреть на все это и засмеяться. [...] Чувство долга - это умение жить, как будто мы всего этого не знаем. Не ерничать, не показывать на мир пальцем, не смеяться» (90-91). В этих словах слышится отголосок призыва Спинозы: «Не смеяться, не плакать, не ненавидеть, а понимать» ${ }^{7}$ (СпинозА 2015 ,

${ }^{7}$ Соболев упоминает этот афоризм Спинозы в книге Евреи и Европа в отношении своего подхода к философии Деррида - не восторженного и не уничижительного, а именно понимающего (СоБолев 2008: 360). Возможно, это свидетельствует о близости концепции Джованни к позиции самого автора. 
глава 1, пар. 4). Речь идет о том философском притворстве, которое является антиподом насмешки и карнавала, его отрицанием: это отказ от смеха, потому что «смех убивает» (91) и обессмысливает все. Жить так, как будто дома нет, можно только находясь внутри него; жить так, как будто смысл есть, можно только находясь внутри бессмысленности как задания осмысления. Отказ от смеха есть поэтому отказ от всевластия, то есть отказ от внешней, тотализующей точки зрения, от объективирующего взгляда потребителя, делающего все видимым и прозрачным (см. СЕНнЕт 2003, БодРийяр 2000), от взгляда «фланёра», любопытного и праздного горожанина. ${ }^{8}$ Этот отказ Джованни называет чувством долга, в смысле долга понимать, вопреки непониманию его собеседника Андрея, видящего в долге нечто противоположное «всего лишь добровольное и бессловесное подчинение власть имущим» (90). И наконец, концепция, высказанная Джованни-Спинозой, объясняет рассуждения о долге последнего из рассказчиков в главе «Дерево и Палестина» долге как противостоянии всевластности и сохранении «тонкого пространства свободы» (434).

Завершая эту феноменологию грусти, седьмой рассказчик подчеркивает невидимость, недоступность, несуществование «оси мира», воплощенной в образе Иерусалима, пустоту, чуждость и «недостижимость профанного» в нем (442). Это наводит на мысль о том значении «дома», которое является противоположностью профанного: название иерусалимского Храма звучит на иврите как «Дом святыни» (Бейт микдаш), а историческое событие разрушения Второго Храма в Иудее в I веке н. э. зачастую именуется кратко «разрушение Дома» (хурбан а-Байт). Грустно то, что жить можно только в профанном, то есть так, как Лакедем, как будто Дома, то есть Храма, нет.

\section{Отказ и религиозная философия}

Тема профанного и священного переплетается с проблемой философии и религии, а также с проблемой свободы как ускользания от власти вещей (434), как одной из центральных проблем метафизики. В этой связи можно заметить, как роман Соболева ведет диалог с Афинами и Иерусалимом Льва Шестова, философа, неоднократно упоминаемого и в книге Евреи и Европа. Шестов видит в европейской философии «отказ от мира и того, что есть в мире», как часть эллинского мышления, в противоположность библейскому. Как следствие, он понимает свободу как свободу от всеобщих и необходимых истин эллинского мышления, от знания, от власти данности. Ему вторит один из героев Соболева: «Истина - это смерть» (363). Путь к свободе Шестов видит в религиозной философии: «Религиозная философия есть... борьба за первозданную свободу и скрытое в свободе божественное „добро зело“, расцепившееся после падения на наше немощное добро и наше всеуничтожающее зло. Наш разум, повторю, опорочил в наших глазах веру: он

${ }^{8}$ См. обсуждение соответствующей концепции Вальтера Беньямина (СоБолЕв 2008: 259). 
„распознал“ в ней незаконное притязание человека подчинить своим желаниям истину и отнял у нас драгоценнейший дар неба, державное право участвовать в творческом fiat (да будет), втолковав и расплющив наше мышление в плоскости окаменевшего est (есть)» (ШЕстов 1993: 335).

Бердяев, вторя Федорову и его философии воскресения, также говорит о творческом и бесстрашном преодолении истории и времени: «Воскресение означает победу над временем, изменение не только будущего, но и прошлого. В космическом и историческом времени это невозможно, но это возможно во времени экзистенциальном. В этом смысле явления Искупителя и Воскресителя» (БЕРдяЕВ 1995: 160-161). Для него царство свободы совпадает с царством истины, и состоит оно в отказе от мира. Если персонализм Бердяева выводит личность за пределы истории, то в персонализме Лосева личность реализуется в истории, что воспринимается как чудо (Лосев 1991: 134160). Поэтому для Лосева вопрос о свободе не стоит так остро, и уж конечно она не видится противоположной истине. Только Шестов идет в этой религиозной философии возможного до конца и понимает, что наиболее свободное творчество - изменение прошлого, победа над временем и смертью - невозможно без отказа от истины, от самого разума, и без принятия мира во всей его исторической конкретности, как он ее понимает, со всем, что в нем есть.

Однако как быть с «немощным добром и всеуничтожающим злом» (см. Шестов 1993: 335), с «кровавым хаосом истории» (443)? Неужели отказ от философских истин «Афин» и выбор «Иерусалима», т. е. выбор веры, в силах превратить зло в добро, снять этическое, сделать противостояние «всевластию зла» ненужным? Если все возможно, согласно Шестову, вопреки нудительной силе истины, то почему именно творчество добра и выход за пределы «окаменевшего есть», факта должны стать выбором индивидуума? Только потому, что для Бога все «добро зело»? Но не является ли это тотальное принятие всего еще одним языком всевластия? Не становится ли тогда философия возможного новым принуждением, нисколько не приближающим к свободе и, к тому же, оправдывающим зло? Не будет ли тогда религиозность или, в случае Соболева, мистицизм лишь бесплодным бегством от факта, от кровавого хаоса истории в избыточность фикции, фантазии, утопии и символа, как это не раз происходило в русской литературе последнего столетия?

В ответ на это трагическое недоумение Соболев строит свой Иерусалим. Всеединству власти здесь противостоит множество путей к свободе, данности противостоит фрагментарность, непрозрачность и случайность бытия (421), истине - тишина и молчание. В отличие от Шестова, Соболев и его повествователи живут в Иерусалиме, поэтому для них религиозно-философская проблема оказывается перевернутой: как сделать вид, что Дома, то есть Храма, нет, как обрести серьезность и грусть расставания, как отказаться от мистической бесконечности возможного и вспомнить о долге заботы о профанной истории, о «кровоточащем мясе мироздания» (410)? Вот почему для него Вечный жид Лакедем - это не миф, а реальный смертный, Самбатион настоящая река, хотя и скрывающаяся за другими названиями, Элиша - герой 
хотя и не написанного, но вполне реалистического романа, а Итиль - столица хотя и давно исчезнувшего, но ни исторически, ни религиозно не устранимого каганата. В том, чтобы сделать бывшее не бывшим, нет никакого чуда, как нет в этом ни спасения, ни воскрешения, ни прощения. Для этого нужно нечто обратное - желание и всевластие. Как и для того, чтобы сделать не бывшее существующим. Однако в этом нет ни истины, ни свободы, ни добра - одна иллюзия.

Для того, чтобы обрести свободу, нужно не чудо и не забвение, а утрата и возвращение к точке слияния черных рек истории, к точке бифуркации, выбора, где истины всегда еще нет, но где она возможна. Святость, как говорит Орвиетта в романе Соболева, это «искусство непринадлежности» (223). Не нудительность, но контингентность истины в точке разлома времени, где все языки погружаются в тишину и пустоту, где история не освящается и не профанируется, а делается предметом молчаливой заботы и созидания - это и есть путь слияния Афин и Иерусалима, предложенный в романе, написанном внутри живого, реально существующего, тонкого и трепетного пространства Вечного Города - подлинного пространства свободы, «покоя и безвременья» (247). Дихотомия Шестова трансформируется у Соболева в выбор между истиной и нарративом как «цельностью истории и понятности» (417) и, тем самым, возвращается к платоновскому противопоставлению диалектики и софистики. Герой Соболева не в силах сделать выбор (227). Вернее, он выбирает сомнение, навязанное самим характером погруженного в войну города, и предпочитает говорить о «вещах в их данности, бессмысленности и конечности» (375).

\section{Заключение}

Эпиграфом к произведению Евреи и Европа Соболев выбрал строки из стихотворения Пауля Целана Nachmittag mit Zirkus und Zitadelle: «da hört ich dich, Endlichkeit, singen, / da sah ich dich, Mandelstamm... Das Endliche sang, das Stete» [«Я слышал, как поешь ты, о конечное, я видел тебя, Мандельштам... Пело то, что конечно, то, что пребывает»]. В главе, посвященной характеристикам еврейской литературы в Европе, Соболев подытоживает свои размышления и пишет, упоминая вновь эти строки Целана: «Еврейскоевропейская литература - это литература конечности» (СоБолев 2008: 213). Важнейшей особенностью этой литературы Соболев считает «демифологизацию языков власти», «всепроникающий скепсис, и в первую очередь скепсис политический» (СоБолЕВ 2008: 204, см. также ВАЙс 2009).

Так и история несостоявшегося математика-самоубийцы в Иерусалиме, и сказка о семерых мужьях Сары и Ашмодее на берегах Двины встраиваются в контекст размышлений Соболева о власти и искусстве, о евреях и Европе, о непринадлежности и сомнении, о вечности и конечном. В этот контекст включаются все главы романа - начиная с конечности Вечного жида и либерализма Ишервуда в главе «Лакедем» - и заканчивая радикальным скеп- 
сисом и бесконечным колебанием без выбора и ответа в главе «Дерево и Палестина». Образ Целана, в особенности в «Двине», где он цитируется наряду с Мандельштамом, служит своего рода символом еврейско-европейской истории, от уничтожения Хазарии до Холокоста, а, возможно, и истории вообще, которая и в Иерусалиме, и в произвдении Евреи и Европа, и в хайфских сказках неоднократно названа хаосом или кровавым хаосом (СоБолев 2008: 86, см. также СоБолев 2005: 443). Вынесенными за скобки этих исторических катастроф оказываются только те, кто свидетельствует о них в своих снах и фантазиях - семеро рассказчиков, исполняющих свой долг у стен отстроенного Иерусалима. Ведь «всякая история... есть не более чем метафора для нашего бытия здесь» (СоБолев 2008: 81).

Так переосмысливает Соболев, скажем в заключение, проблему «бытия и времени», сводя их вместе как створки одной метафоры, и, в то же время, бесконечно разводя их, и тоже внутри этой метафоры. Это внутри нее возникает то тонкое пространство свободы, которое ищет автор и все его разноголосые повествователи. Свобода, согласно поэтической детерминистическихаотической философии Соболева, может быть как отчуждением и грустью, так и счастьем и отождествлением; как словом, так и молчанием; как отказом, так и долгом; как конечным существованием, так и вечной истиной. А иначе, какая же это свобода?

\section{Источники}

СоБолев 2005 = СоБолев Д. Иерусалим. Ростов-на-Дону: «Феникс», 2005.

СоБолев 2008 = СоБолев Д. Евреи и Европа. Москва: «Текст», 2008.

СоБолев 2011 = СоБолев Д. Поезд Хайфа-Дамаск. Журнал «22». № 159. 2011. http:// www.sunround.com/club/22/159_sobolev.htm.

\section{Литература}

АдоРно 2000 = АдоРно Т. Проблемы философии морали. Москва: «Республика», 2000. АРендт 2008 = АРендт Х. Банальность зла. Эйхман в Иерусалиме. Москва: «Европа», 2008.

Атоев 2015 = Атоев А. М. Проблема свободы выбора в «Шахнамэ». Bonpocы философии 2015/12: 193-197.

БАХТИН 1986 = БАХТИН М. Автор и герой в эстетической деятельности. В кн.: Эстетика словесного творчества. Москва: «Искусство», 1986. 9-190.

БЕРДЯЕВ 1995 = БЕРДЯЕВ Н. Царство Духа и Царство Кесаря. Москва: «Республика», 1995.

БодРийяр 2000 = БодРийяр Ж. Символический обмен и смерть. Москва: «Добросвет», 2000.

ВАйс 2009 = ВАЙс Р. Евреи и власть. Москва: «Текст», 2009.

Гуляев $2015=$ Гуляев Р. В. Философ перед лицом бессловесного ужаса («Вий» Н. В. Гоголя). Вопросы философии 2015/9: 102-113.

ДЕЛЁз-ГВАТТАРИ 2010 = ДЕЛЁз Ж., ГВАТТАРИ Ф. Тысяча плато. Капитализм и шизофрения. Екатеринбург: «У-Фактория», Москва: «Астрель», 2010. 
ДостоЕВский 1982 = ДостоЕВский Ф. М. Собрание сочинений в 12 томах. Т. 11. Братья Карамазовы. Москва: «Правда», 1982.

ЗИНГеР 2013 = ЗиНГеР Н. Черновики Иерусалима. Москва: «Русский Гулливер», 2013.

КАГАН 2004 = КАГАН М. Иван Сергеевич Тургенев. В кн.: О ходе истории. Москва: «Языки славянской культуры», 2004. 576-584.

ЛЕВИНАС 1998 = ЛЕВинаС Э. Время и другой. Гуманизм другого человека. Санкт-Петербург: Высшая религиозно-философская школа, 1998.

ЛЕвинзон 2013 = ЛЕВинзон Л. Гражданин Иерусалима. Новый журнал. 2013. № 273. http://magazines.russ.ru/nj/2013/273/21.html.

ЛЕвицКий 1995 = ЛЕвицкий С. Трагедия свободыл. Москва: «Канон», 1995.

Лосев 1991 = Лосев А. Диалектика мифа. В кн.: Философия. Мифология. Культура. Москва: «Издательство политической литературы», 1991. 21-186.

ЛотмАН 2000 = ЛотмАН Ю. Культура и взрыв. В кн.: Семиосфера. Санкт-Петербург: «Искусство», 2000. 12-149.

МИХАЙЛИЧЕНКО-НЕСИС 2004 = МИХАЙЛИЧЕНКО Е., НЕСИС Ю. И/е рус.олим. 2004. httр:// www.lib.ru/RUSS_DETEKTIW/NESIS/je_rus_olim.txt.

Никитин 2002 = Никитин С. В. Научная рачииональность и свобода. Дисс. ... докт. филол. наук. Саратов: Саратовский государственный университет. 2002.

Николис-Пригожин 2003 = Николис Г., Пригожин И. Познание сложного. Москва: «УРСС», 2003.

Ороьий 2014 = ОроБий С. Литература и свобода. Homo Legens 12 (2014). http://homolegens.ru/2014_4/oblako/sergey-orobiy-literatura-i-svoboda/.

РикёР 1998 = РикёР П. Время и рассказ. Т. 1. Москва-Санкт-Петербург: «Университетская книга», 1998.

РуьинА 1996 = РуБинА Д. Вот идет Мессия! Москва: «Остожье», 1996.

РуБинА 1998 = РуьинА Д. Последний кабан из лесов Понтеведра. Испанская сюита. Иерусалим: «Pilies Studio Publishers», 1998.

РуБина 2004 = РуьинА Д. Синдикат. Роман-комикс. Москва: «Эксмо», 2004.

СЕннет 2003 = СЕннет Р. Падение публичного человека. Москва: «Логос», 2003.

СпинозА 2015 = СпинозА Б. Богословско-политический трактат. Москва: «Академический проект», 2015.

СТЕКЛОВА 2015 = СТЕКЛОВА И. В. ОНТоЛогический аспекТ истинЫ и свободЫ. Известия Саратовского университета. Новая серия. Серия «Философия. Психология. Педагогика» 2015/4: 51-55.

ФЕДОТОв 1989 = ФЕДОТОВ М. Иерусалимские хроники. http://lib.ru/NEWPROZA/FEDO TOW/ierusalim.txt.

Фромм 2011 = Фромм Э. Бегство от свободы. Москва: «АСТ», 2011.

Шестов 1993 = Шестов Л. Сочинения в 2 томах. Т. 1. Афины и Иерусалим. Москва: «Наука», 1993.

ЭПшТЕЙН 2001 = ЭПштЕйн М. Философия возможного. Модальности в мылилении и культуре. Санкт-Петербург: «Алетея», 2001.

Юдсон 2013 = Юдсон М. Лестниияа на шкаф. Москва: «Зебра Е», 2013.

ЯСПЕРС 1991 = ЯСПЕРС К. Смысл и назначение истории. Москва: «Политиздат», 1991.

COHEN 2005 = COHEN H. Logik der reinen Erkenntnis. Hildesheim: Olms, 2005.

Ricoeur 2004 = Ricoeur P. Memory, History, Forgetting. Chicago: The University of Chicago Press, 2004. 